\title{
Notes on the Variety and Uses of Satire, Sarcasm and Irony in Social Research, with Some Observations on Vices and Follies in the Academy
}

\author{
CATE WATSON \\ School of Education, University of Stirling, United Kingdom
}

\begin{abstract}
In this article the author examines the uses of satire and its rhetorical devices, sarcasm and irony, in social research, analysing published research papers as well as drawing on her own autoethnographic data. In particular, she focuses on texts concerning discourses within the academy and the current predicament of the academic, each of which sets out to expose an aspect of the workings of power in institutions. While satire may be considered a narrative form, a means for and of representation, irony, as a rhetorical trope which exerts its effects through juxtaposition and the creation of incongruity, constitutes a potential analytical tool in social research, overturning expectations and operating within a 'logic of discovery'. Satire therefore functions as a form of critical analysis while irony contributes to the development of theory and 'paradigm innovation'.
\end{abstract}

\section{Introduction}

In this article I examine the contribution of satire, sarcasm and irony to social research, arguing that these rhetorical devices have a thoroughly serious, though under-utilised (and perhaps misunderstood) role as methodological tools in the social sciences. In particular, I focus on published texts concerning discourses within the academy and the current predicament of the academic, each of which sets out to unmask the workings of power in the production of the 'reality' under which we labour. I also draw on some of my own autoethnographic fragments, gathered as part of an ongoing interest in the mundane, following the precept of Erving Goffman that one should 'treat one's entire life as data' (cited in Strong, 1983, p. 348).

\section{Satire, Sarcasm and Irony}

Satire is dangerous stuff. According to Elliott (1954), ancient beliefs in the magical powers of satire for good and ill were widespread. Satire could be hurled as invective against one's enemies or used to expel evil. That satirists could 'rhyme rats to death' (Elliott, 1954, p. 241) was apparently a commonplace belief in ancient and medieval times, referred to by Shakespeare and others, and the possible source of the legend of the Pied Piper of Hamelin. While satirists may no longer be feared for their terrible power, ruthlessly exercised (rats may sleep easy in their nests), the metaphor of satire as weapon persists. It is perhaps satire's conceit to present this as having moral purpose, to 'mend the world', as Jonathan Swift put it (Holloway, 1956, p. 20). Indeed, satire has been defined as 'a literary manner which blends a critical attitude with humour and wit to the end that human institutions or humanity may be improved' (Thrall et al, 1960, cited in Harris, 1990); it is 'a mode of challenging accepted notions by making them seem ridiculous' (Bronowski \& Mazlish, [1933] 1960, p. 252), a form of attack whose purpose may not be to bring about change but to focus perceptions (Knight, 2004). Satire has a long and honourable history as a means of exposing vice and folly, 
revealing the workings of power and providing valuable social and political comment. But the satirist occupies an ambiguous position in society, always skating 'on the thin edge of censorship and legal retribution' (Elliott, 1954, p. 244), even in what we consider to be these enlightened times, and 'never quite certain himself whether he will be acclaimed or punished' (Burke, 1939, p. 276).

Satire, whether considered as genre or mode of writing (that is, as 'a tone and an attitude' [Real, 2005 , p. 512]), frequently makes use of other rhetorical devices, such as sarcasm (which is distinguished by its bitter and caustic nature [Gibbs, 2007]) and, especially, irony. While irony is a difficult term to define, with many variants - dramatic, verbal, situational, Socratic, etc. - the most common definition, according to Colebrook (2004, p. 1), is 'saying something contrary to what is meant'. Though she regards this as simplistic almost to the point of uselessness, it immediately throws up problems for the social scientist who is, generally speaking, discouraged from doing this sort of thing. However, while satire (and sarcasm) may be considered narrative forms, means for and of representation, irony, as a rhetorical trope which exerts its effects through juxtaposition and the creation of incongruity, constitutes a potential analytical tool in social research, overturning expectations and operating within a 'logic of discovery'. Irony is 'a metaphor of opposites, a seeing of something from the viewpoint of its antithesis' (Brown, 1989, p. 174), and it is the ability to do this which constitutes the art of social science. Indeed, Brown contends that 'the prime instrument of sociological knowledge is an eye for paradox, contradiction and reversals that are latent beneath the more obvious manifest content of action' (p. 178); and he goes on, '[T]he sociologist must "estrange" taken-for-granted reality so that it appears in a new and previously unsuspected light; he must be the man who shouts "Theatre!" in the middle of a crowded fire' (p. 183).

Satire has a 'protean quality' (Knight, 1992), imitating other genres and 'borrowing its ground plan parasitically and by ironic inversion, from other forms of ordered expression in art or in life' (Stopp, cited in Knight, 1992, p. 22). Satire puts on formal disguises, hiding its identity in order to sharpen its attack, but its key feature is wit:

Once wit has been brought into the service of the satiric impulse, then all the stock devices by which the literary satirist achieves his end become available: irony, burlesque, innuendo, the beast fable, the imaginary voyage, allegory - all the devices of indirection which make the study of satire so fascinating and so confusing. (Elliott, 1954, p. 245)

While this may be all very well in literature, it represents a problem for the social researcher. As Fine $\&$ Martin note, a predominant characteristic... of scientific discourse generally is its serious and sedate mien' (1990, p. 89). Yet the social sciences as a field of practice are not entirely devoid of wit. One of the finest exponents of this is Erving Goffman. Fine \& Martin analyse sarcasm, satire and irony as 'overlapping humorous techniques' drawn on by Erving Goffman in works such as Asylums (Goffman, [1961] 1991), in which 'mental patients serve as moral exemplars for the rest of us'. By overturning our expectations of what constitutes rational/irrational behaviour, Goffman succeeds in challenging power relations in institutions, and the measured academic style with which he does this only intensifies his attack. Yet Goffman has been dismissed in some quarters as lightweight - a humorous writer but a second-rate sociologist:

It is still too easy to dismiss Goffman's main work as amusing, interesting but minor... as the product of a light essayist, not a scientist; as dealing with micro-trivia rather than macrostructure; or, most seriously of all, as fundamentally immoral, as taking a cynical, manipulative and ultimately destructive view of humanity. There is therefore a discrepancy between his reputation in various sub-disciplines and his overall status as a sociologist. (Strong, 1983, p. 345)

The problem, as Strong (1983, p. 346) sees it, is this: 'In neither its style nor its content does it fit the disciplinary norm, and many of the problems in its reception may be traced to its academic oddity.' The nineteenth-century economist Thorstein Veblen is another whose unorthodox prose style offended the academy. Conroy (1968, p. 605) says that when Veblen's most famous work, The Theory of the Leisure Class (1899), was first published, 'it was frequently misread as a literary satire of the nouveaux riches of the period' [original emphasis] which missed entirely the seriousness of his social and economic criticism. This dismissal of serious critique as 'just a bit of fun' highlights the way in which genre expectation on the part of readers, not to mention the gatekeepers to publication, acts powerfully as an ideological effect and form of policing in the social sciences. 
Having set out this apologia, I now move on to examine the uses of satire, sarcasm and irony in social research.

\section{Satire, Sarcasm and Irony in the Academy}

Satire

My first example is Stronach's (2007) article 'On Promoting Rigour in Educational Research: the example of the RAE'. In one sense it might be argued that the RAE (the Research Assessment Exercise [1]) presents an easy target for satire (as so many practices in the academy do), but Stronach's analysis is no less cogent (or entertaining) for that. Stronach starts off in satirical mode, setting out the aims of the article, the purpose of which is to

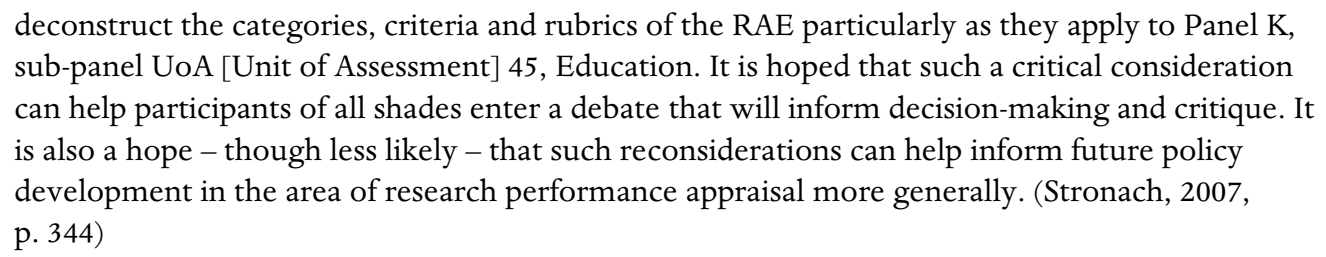

Stronach then analyses the processes by which the criteria for judging the quality of research as set out in the RAE - Significance, Rigour and Originality - were arrived at. In doing so, he succeeds in demonstrating a rather less than rigorous approach, bordering indeed on sharp practice (though I should add this is my interpretation, not Stronach's). In particular, his attack is focused on the education sub-panel's preoccupation with the criterion of Rigour itself, a concern which is apparently lacking in other disciplines "more readily called "science" than educational research or indeed psychology' (Stronach, 2007, p. 345). Could it be the case, Stronach asks, that 'science' is operationalised as rigour within the RAE sub-panel process 'in order to make an honest woman of Educational Research?' (p. 346). By pointing up the lack of rigour in the process by which rigour came to occupy its pre-eminent position in the education sub-panel of the RAE, Stronach effectively shakes the foundations, calling into question the validity of the whole exercise. Indeed, the process descends into farce at one point as it emerges that in one of the workshop events set up to gauge the opinions of academics about the criteria to be adopted for ranking research (carried out by Wooding \& Grant, 2003, cited in Stronach, 2007), Stronach uncovers a curious anomaly:

Although originality had been highly rate by other workshops, there was a zero score for one workshop. It seemed unlikely that a group of academics would be so uninterested in 'originality'. Further exploration revealed an explanatory footnote:

'The sticky hexagon fell off the chart and was not available for voting'

... An averaging of the other workshop scores for that category... was not undertaken, and instead the presumption of a 0 score was made. (p. 347)

The scientific rigour with which this absurdly irrational decision is arrived at further satirises the academy and its workings. In this way, Stronach's account concerning the events underlying the development of the RAE succeeds in exposing vices (and follies) within the academy.

It might be objected that this account, being 'true', does not qualify as satire, sensu stricto. However, this would be to buy into a form of literary realism which supposes that narrative mediates events transparently. But more interesting than the question of whether satire can relate to 'true' events or not is the satirical mode in exposing, without heavy-handed analysis, the absurdity which is masked by hegemonic rational discourses. Lippitt (1999, p. 451) suggests that 'the thinker' who approaches 'questions in an inappropriately "objective" manner is in the grip of an illusion' and that satire has a role to play in dispelling such illusions. Further, that as a weapon it is often much more effective in achieving this than other 'direct forms of critical argument'. In this way, satire constitutes an incisive analysis obeying the principle of economy (Muecke, 1982, p. 52) which aims at 'the production of the supreme effect through the least extravagant'. Stronach's sticky hexagon exemplifies this principle to perfection. The principle of economy is also at work in the following example which concerns the almost feverish restructuring of universities that is 
currently going on, with 'departments merging in unexpected ways to create units that conform only to the logic of the market' (Watson, 2010, p. 11). This was neatly satirised in the following manner at a conference on academic identities:

Scottish University announces re-structuring

A University announced today that the Department of Maths is to merge with the Institute of Sport to make a department which can work out if it's still mathematically possible for Scotland to make it to the next World Cup finals...

This may have meant more to the local audience than those world-wide, but you probably get the point. (Interestingly, following this presentation it came to light that the newly created Faculty of Arts, Business and Science at a university somewhere in the north of England is known locally as the 'Fac All'.)

Working in the academy provides many examples of what might be referred to as the absurd, an awareness of which becomes a tool for the exploration of academic discourses, as Stronach's example indicates. There may, however, be ethical difficulties in representing such events. The rise of codes of ethics in research, over and above the moral injunction to do no harm, can be regarded as a form of censorship. As Humes (2011, p. 175) notes with delicate irony, this provides 'fertile territory for academic bureaucrats to exercise their "gatekeeping" fetishes'. One way to try to sidestep this criticism is to present fictionalised accounts - for example, 'creative non-fiction' (Hackley, 2007) and 'semi-fiction', in which 'empirical content is presented in a partial (or total) make-believe form for dramatic communicative effect' (Whiteman \& Phillips, 2006, p. 6). As fictionalised accounts, satirical forms of representation may enable the writer to escape censure (though Burke's warning, quoted earlier, resonates). The following is a case in point, a semifictional account which satirises the follies of academia. While the account is based on 'real' events, the representation constitutes a critical analysis of these events, obeying Muecke's principle, intended to highlight the irrationalities inherent in organisations.

Minutes of the annual university staff assembly ...

The annual whole university 'staff assembly' assembles in what are generally acknowledged to be 'very challenging times'. First (ostensibly to dispel the gloom, but in effect to berate the rest of us), the Principal of the University gives us the good news - two members of academic staff have won prizes. Even more impressive, the registry has been nominated in the 'registry services of the year' awards! (I imagine a C-list celebrity fumbling with a gold envelope and announcing 'And the nominations are ...' followed by an audible intake of breath from the audience.) Then the Principal hands over to 'a finance director' and we are whisked through the current situation: uncertainty ... period of pressure ... funding cuts ... belt tightening. And our options are laid out: restructuring ... down-sizing ... necessity to find new niche markets (that euphemism for the new academic colonialism). Excellence must be at the heart of everything we do. Ominously perhaps, we are told that most money goes on the wages bill. More ominously, we hear, staff who have research in their contract but who were not judged to be performing sufficiently well to be returned in the last UK research assessment exercise have been EXTERMINATED (sorry, that should read 'reviewed'). Then it's back to the Principal and time for Q+A. A long pause. Finally, an academic at the back stands up. He has two questions. The first concerns dogs on campus. The Principal, who clearly recognises a potentially awkward question when he [or in the interests of anonymity it might be 'she'] hears one, deftly bats this to one of the senior management 'team':

Senior Management: Yes, I think I can answer this. There used to be a ban on dogs on campus, but new legislation has been introduced which is in effect an equivalent of the 'right to roam'.

Academic: Dogs have a right to roam?

Senior Management: [laughs uncertainly] Well, no, not quite. The law allows members of the public to enjoy the facilities, and walking dogs is one of the ways they can do this, er, as long as the dog is under control. 
Variety and Uses of Satire and Irony

Academic: How is that defined exactly?

Senior Management: Well [brightly], it depends on the individual dog. For some dogs this will mean being on a lead, for others they might be running about.

Academic: How can I judge if the dog is under control if it is running about?

Senior Management: Well, for example, if the dog is well trained it will come to heel when called.

Academic: How do I know if a dog is well trained if it is running towards me?

Senior Management: If a dog comes towards you, and it is well trained, it will return to its owner when called.

Academic: Suppose the owner doesn't call it

Senior Management: I think you have to give it a chance

Academic: But maybe I don't want to give it the chance. If a $6 \mathrm{ft}$ dog is coming towards you ...

Senior Management: [Looks relieved, this hyperbole clearly undermines the case] Come now, $6 \mathrm{ft}$ ! [Then, in an effort to close this down] Obviously no dog should be allowed to worry wildlife - or members of staff. [audience laughs dutifully] You had a second question.

Academic: Yes. It's about car parking permits ...

[Audience roars]

The account resists the urge to closure through providing 'an interpretation' (see Sparkes, 2007): is it deeply parochial, illuminating the academic in their ivory tower (from which they have descended at lunchtime for a little fresh air) - or deeply subversive, undermining the attempts of management to cover itself with the appearance of rationality? As satire, the account attempts to draw out the irony inherent in these both/and relations.

\section{Sarcasm}

As noted earlier, sarcasm is defined by its intention to wound. This renders it more problematic in terms of social science than either satire, which has moral purpose, or irony (as I have defined it here) as 'a metaphor of opposites' with analytical intent. Sarcasm therefore may be open to the charge of offering merely gratuitous insult. Sarcasm, Fine \& Martin (1990) suggest, is the least kindly form of humor... one trades one's halo to do the Devil's business. Effective though it is, some negativity rubs off on the sarcaster' (p.97). Indeed, I found this to be very true. On submitting to a very respectable journal an autoethnographic paper on academic identities, in which I used the representational device of personal diary entries, I was 'advised' by one reviewer to remove a 'sarcastic' reference to the self-proclaimed Russell Group of research-intensive UK universities (named for the London hotel in which this cabal first got together) which, the reviewer felt, reflected badly on the author (and autoethnography):

Diary entry:

Attend research seminar in London. Decide to stay at the Russell Hotel, drawn by its exciting and glamorous associations! (Most academics you meet who work at Russell Group institutions usually let this slip within the first few minutes - especially if it is one of the more surprising of these, like Nottingham). So I am keen to experience the sumptuous Victorian pile where it all began. As befits my status from a non-Russell Group Institution I am given a tiny room by the lift shaft, overlooking the wheelie bins. A materialisation of my academic identity.

Accordingly, this diary entry never made it into print [at least not in that particular journal - Ed.]. Yet, it could be argued that it does indeed give insight into the ways in which academic identities are both produced and performed, and therefore makes a serious and legitimate point. 
Irony

While satire is a genre or mode of representation and can appear in many guises, irony has a more formal quality as a 'metaphor of opposites' (Brown, 1989, p. 80). It is this antagonism that renders irony a useful analytical tool in social research, enabling exploration of the paradoxes and contradictions within the discourses that frame action. Irony is therefore an analytical tool which depends on a destabilisation of opposites and the movement towards an inevitable outcome. Drawing on this relation, Brown (1989, p. 184) formulates 'the law of irony' which, put briefly, states that 'when the highest degree of incongruity is combined with the greatest degree of inevitability, there results a statement of the greatest theoretical value'. By way of illustration, he gives the following example:

'We are brothers under the skin' is not a substantial contribution to knowledge when said of one's cousin or friend ... but we do find it news that GIs and Nazis bear a family resemblance. (p. 186)

In similar manner, Goffman ([1961] 1991) uses the concept of the 'service relationship' to draw out unexpected similarities between the way in which car mechanics and psychiatrists relate to their objects of professional concern; and Helen Gunter's (1995) article 'Jurassic Management: chaos and management development in educational institutions' presents a parable drawing out analogies between management failures portrayed in the best-seller Jurassic Park (Crichton, 1990) and failures in educational leadership policy. (By doing this, Gunter not only unmasks an unexpected similarity, she is also able to suggest that current conceptions of educational leadership and management are based on an outmoded and discredited model pedalled by a bunch of dinosaurs.) As well as unmasking unexpected similarities, ironic analyses can also uncover unsuspected differences and the 'interdependency of opposites' (Brown, 1989, p. 191), as in the following examples: the 'Utopian paradox' which asserts that 'virtue and goodness lead inevitably to social collapse' (Polak, 1961, p. 21); taxonomy, as the science of classification that attempts to impose closure results only in its infinite deferral (Watson, 2008, p. 124); rote learning of poetry, which, far from being a repressive pedagogical practice, in fact enables us to 'suffer awakening to the poem's otherness' (Munday, 2009 , p. 85); and in a general way, Virilio's notion of the 'integral accident' as that inherent principle in technology which brings about its own destruction (Virilio, 2001, 2007).

Tools familiar to researchers of a postmodernist/poststructuralist bent are based on this notion of the destabilisation of opposites: Derridean deconstruction, for example, which seeks out 'the unspoken, the implicit and the contradictory' (Stronach, 2007, p. 344), and Foucault's genealogical analyses which are, Fendler (2004, p. 461) argues, 'infused with irony'. Fendler defends this use of irony in social research against those who hold the view that both satire and irony belong 'outside the limits of critical rationality' and consequently have nothing to contribute to science, social or otherwise. This, she suggests, is to be reductive about knowledge in a way that is itself irrational: 'In Foucault's historiography,' Fendler says, 'the value of reason is not diminished by the inclusion of irony; rather, the value of reason is fortified by constructing reason in a more robust way' (p. 461).

Some concepts seem inherently ironical, embodying a dialectical tension, and therefore especially useful as tools for analysis. Deleuze \& Guattari's ([1972] 2004) paradoxical concept of the Body without Organs, for example, permits an analysis of subjectivity and desire which sees the subject emerge as an after effect of desire rather than as an agent of it (Watson, 2008). Another example is Slavoj Žižek's (1998) concept of 'interpassivity', the outsourcing of enjoyment through the delegation of passivity to some other object. Žižek gives as examples the VCR that watches television for you; the 'canned laughter' that replaces your own; and, curiously, 'the artist who eats your sandwich for you' (cited in van Oenen, 2008). Žižek explains:

I am passive through the Other. I concede to the Other the passive aspect (of enjoying), while I

can remain actively engaged (I can continue to work in the evening, while the VCR passively

enjoys for me). (Žižek, 1998, p. 10)

The sense of 'enjoyment' here is the injunction to enjoy, predicated on the idea that our enjoyment is never spontaneous but emerges from the super-ego imperative: 'Enjoy!' (Žižek, 1998, p. 9) 
(which invariably robs us of any sense of enjoyment). In this way interpassivity relieves us of 'the monstrous duty to enjoy' (p. 9).

Academic life furnishes the example of the habit of downloading papers that you never read, the act of reading being delegated to the printer (though the notion of 'enjoyment' may be a little strained in this example); and Googling, in which the computer does your research for you (ditto). As an analytical tool, the concept of interpassivity functions in the 'logic of discovery', resulting in interesting juxtapositions. Through it we glimpse, in the example just given, that what is not in the electronic domain becomes virtual, existing only in the increasingly liminal space of materiality. Johnsen et al (2009) use the concept of interpassivity to theorise cynicism in the workplace, showing how 'cynicism serves as a conservative force' which, 'rather than presenting a resistance to the normative gestures in contemporary work-settings, in fact sustains these gestures' (p. 204). The authors characterise the cynical employee as one who recognises 'the power interests behind the injunction to self-actualize at work' (p. 203) but goes along with it anyway. This depends on the construction and maintenance of 'an authentic self who interpassively delegates enjoyment of work to a 'corporate self. Cynicism is theorised as the mechanism through which this exchange is enabled and sustained.

Irony depends on a process of unmasking [2], making that which is dissimilar also similar, or vice versa, but Brown (1989, p. 186) cautions that 'pointing out hidden relationships between opposites, or oppositions within apparent unities, will constitute "a discovery" only to the degree of incongruity that is noted in the terms and that is established between the new formulation and prior expectations'. My next examples both use irony as an analytical tool in this way: Holligan (2010) unmasks academia to show how it is feudal in its operation; Kavanagh (2009) portrays the university as Fool.

In 'Feudalism and Academia: UK academics' accounts of research culture', Chris Holligan argues that there has been a deterioration in the conditions of intellectual work and that 'contemporary academia can reasonably be understood in terms of the transactions and hierarchical dependencies characterised by a medieval feudal order' (2010, p. 4). Holligan uses this 'ethnographic analogy' to explore relations in the academy using concepts derived from feudalism (cultivating the land; cycles of tribute; and the temporal order) to construct thematic framings around the work of academics. In this analysis, academics have become peasants, victims of a regressive regime: 'casualties of capitalism who, to survive, have to devise more efficient cultivation techniques or make more effort with fewer resources' (p. 9). As part of the system, academics must pay tribute, in the form of research outputs, to powerful Lords (who control the purse strings), as a result of which knowledge production is circumscribed, assessed in terms of some putative notion of 'impact'. Holligan uses this analysis to point up the emergence and current pre-eminence of 'mode 2' knowledge (Nowotny et al, 2003). Finally, the academic, like the peasant, has their time 'defined by the seasons of nature and the personality of his masters'. In the case of the academic, there has been an intensification of work in the academy, resulting in an 'unrelenting pressure' which threatens to erode distinctions between work time and personal time (though payment of greater tribute may result in the ultimate reward of research time). Moreover, for the academic, time is increasingly parcelled up into unrecognisable units measured by systems of accountability such as Trac, the transparent approach to costing, which, since 2000 , has been the standard methodology used by higher education institutions in the UK for costing their main activities (HEFCE, 2005). Such forms of accountability create a curious sense of dislocation from the lived experience of intellectual work (Watson, 2010).

Holligan's analysis points up the current parlous state of the academic and the extent of their descent, particularly in terms of loss of the traditional and cherished (though somewhat nebulous and nostalgic) concepts of academic freedom and autonomy. The analogy is a startling one which, Holligan argues, has serious implications both for us peasants working in academia and for the future of universities themselves as globalization gives rise to what Urry (2002) refers to as neomedievalism, in which powerful fiefdoms such as the Russell Group fight for territory and scarce resources and universities' dependence on imperial patronage in the form of powerful overlords such as Bill Gates increases. Meanwhile, 'wandering intellectuals (academic mercenaries?)' (Urry, 2002, p. 28) sell their services to the highest bidder.

In 'Institutional Heterogeneity and Change: the university as fool', Donncha Kavanagh (2009) also turns to a medieval concept in analysing the university as a 'foolish institution'. Drawing on 
Weick's (1989) notion of theory construction as 'disciplined imagination', further developed and augmented by Cornelissen (2006), Kavanagh uses the metaphor of the Fool to develop theory concerning institutional change and the university. How useful is this metaphor? The Fool in literary terms is a character full of 'ambiguity and paradox', with a 'fetish for garish costumes' (Kavanagh, 2009, p. 587) (so far so good). The Fool has many faces and plays many roles but is always linked symbolically to the King. Kavanagh argues that over time the university has accepted a position in relation to a range of 'sovereign bodies' - Church, nation, the professions, the corporation, etc. - as that between a Fool and his King, which has resulted in the creation of an institution riven by a series of dialectical tensions or fault lines. In this analysis the very idea of the university itself becomes deeply ironic (or does it?). Thus, Kavanagh says, 'while some might pine for Kant's university of reason or the University of culture, the contemporary university is better understood as the institutional manifestation of modernity's ontological uncertainty, insecurity and ambiguity' (p. 586).

Next, Kavanagh says, the Fool is a 'normative narrator' with a story-telling role, critically interpreting the world, and is expected to reveal the truth. These stories are addressed to a number of audiences: the Fool speaks to his sovereign, to other characters in the play, directly to the audience outside the play - and 'essentially with himself (the Fool is usually, though not invariably, male). The Fool at times will bow to his sovereign, but he is also an independent critic and interpreter of the world. Along with his story-telling role, Kavanagh argues, there is a sorting role which the fool achieved through a discriminating eye and agile wit, but which in the university is achieved through its numerous practices and technologies (dependent, in part, on the particular sovereign being served). Through these practices of normative narrating and sorting, the university 'realizes its imagined community of academics' and so becomes an institution (p. 588).

The Fool is licensed to play the fool, instigating chaos and overturning received wisdom, but he must be careful not to transgress too far, for ultimately the Fool's role is to sustain order. This relationship is a delicate one, and Kavanagh argues there are times when the balance is lost: the Fool transgresses the role and forgets to play, or thinks he is himself the sovereign. In another form of transgression, the Fool forgets that his role is to sustain order:

Within the university setting, the decline of the academic lecture into public farce during the 18 th century, the excesses of postmodern self-indulgence, and the careerism underpinning much statistical and interpretative sophistry are perhaps good examples of this kind of transgression. (Kavanagh, 2009, p. 589)

Finally, the Fool is an educator, 'an irritant, a provocateur, whose modus operandi is to provoke new wisdom in others' (p. 590).

Kavanagh regards his article as a contribution to institutional theory which focuses on the heterogeneity and mix of conflicts within the institutional environment. The metaphorical analysis is used to contribute to theory concerning institutional change which directs its focus at the macrosociological level of institutional relationships over time. This, Kavanagh argues, runs counter to the prevailing dominance in social theory which 'has been to understand macro phenomena through detailed study of situated practice' (Kavanagh, 2009, p. 591).

While there are similarities between Holligan's and Kavanagh's metaphors, there are differences too. In both articles the metaphors presented are incongruous, the juxtapositions surprising, obeying the first part of Brown's law of irony. In Holligan's case, the metaphor upsets some ideas dear to the identity of the academic - namely, academic autonomy and freedom. Far from being the autonomous intellectual, the current predicament for the academic is serfdom. In Kavanagh's article, the focus is on the institution rather than the academic, but again, notions of autonomy are called into question, though the relationship is altogether a more ambiguous one than is indicated by Holligan. Through Kavanagh's analysis we see the current context as one in which the university's role as Fool has been transgressed, perhaps through acceding too much to its sovereign(s), but we also sense the difficult balancing act to be maintained in this relationship in which 'independence', and the desirability/impossibility of achieving this, are subtly but effectively critiqued. 


\section{Conclusions}

I have here attempted to maintain a distinction between satire and irony which is based on their respective use functions in social research. In broad terms I have characterised satire as a narrative form (which is nevertheless heavily reliant on irony for its effects) and irony as a rhetorical trope which serves as a tool for the development of theory: in this taxonomy, the purpose of satire is critical analysis, while irony serves as 'an instrument of paradigm innovation' (Brown, 1989).

The satiric impulse, I noted at the outset, is characterised by wit, and against those who regard the comedic as a trivialising device, I argue that satire has a potentially serious role to play in social research. Fendler (2004) argues that the role of the intellectual is to embody a critical attitude', to adopt a kind of pessimistic activism (borrowing Foucault's phrase), an ironic concept through which we recognise that everything is dangerous and therefore there is always something to do (though we should be under no illusion that this will necessarily make anything better). The satirist as intellectual critic takes on the role of the pessimistic activist. But satire has an additional purpose. Lippitt (1999) analyses Kierkegaard's satirical attack on Hegel which he wrote pseudonymously as 'Johannes Climacus' in the Concluding Unscientific Postscript ([1846] 2009). In this, Climacus argues that the follower of Hegel is in the grip of some illusion and that satire is needed to rid them of this, but 'a direct "moralising" attack would be pointless'. What is required is a change of outlook, and laughter is what brings this about: 'Here, then, a laughter of non-discursive dismissal can liberate us from the sense of feeling obliged to argue against the System on its own terms' (Lippitt, 1999, p. 461, emphasis added). Laughter frees us, however briefly, from the grip of the discourses within which we are immersed and enables us to glimpse something else. Similarly, Critchley (2002, p. 35) says that satire asks us to 'look at ourselves as if we were visitors from an alien environment... [W] hen we do this we begin to look like outlandish animals and reasonableness crumbles into irrationality.' Irony is the trope that brings this about. By unmasking unexpected correspondences and unsuspected differences, irony achieves 'a derealization of the conventional in order to re-realize it in a more cogent and illuminating form' (Brown, 1985, p. 581). In this, irony draws on a notion of research in the baroque (MacLure, 2006; Watson, 2008), arising in what Spieker (1995, p. 277) refers to as the crisis of similarity: 'By representing the similar as that which is also dissimilar, the harmonious as that which is also disharmonious, and the beautiful as that which is also ugly, the baroque calls into question formerly self-evident correspondences.' Satire and irony therefore disrupt discursive understandings and by so doing reveal the workings of power, but this too is not without its ironies:

Satire is a sort of glass wherein beholders do generally discover everybody's face but their own. (Swift, preface to the Battle of the Books, 1704)

\section{Notes}

[1] The Research Assessment Exercise is the means by which research in UK universities is assessed and through which they receive research funding. It was last held in 2008.

[2] By this I do not mean to suggest that what is revealed is 'reality', except in the sense in which Muecke (1982, p. 34) uses it: "Reality", as the word is used here, is to be taken as meaning only what the ironist or ironic observer sees as such.'

\section{References}

Bronowski, J. \& Mazlish, B. ([1933] 1960) The Western Intellectual Tradition from Leonardo to Hegel. London: Hutchinson.

Brown, R.H. (1985) Narrative, Literary Theory, and the Self in Contemporary Society, Poetics Today, 6(4), 573-590.

Brown, R.H. (1989) A Poetic for Sociology. Chicago: University of Chicago Press.

Burke, K. (1939) The Calling of the Tune, Kenyon Review, 1(3), 272-282.

Colebrook, C. (2004) Irony. London: Routledge.

Conroy, S.S. (1968) Thorstein Veblen's Prose, American Quarterly, 20(3), 605-615. 
Cornelissen, J.P. (2006) Making Sense of Theory Construction: metaphor and disciplined imagination, Organization Studies, 27(11), 1579-1597.

Crichton, M. (1990) Jurassic Park. London: Random House.

Critchley, S. (2002) On Humour. London: Routledge.

Deleuze, G. \& Guattari, F. ([1972] 2004) Anti-Oedipus: capitalism and schizophrenia. London: Athlone Press.

Elliott, R.C. (1954) The Satirist and Society, ELH, 21(3), 237-248.

Fendler, L. (2004) Praxis and Agency in Foucault's Historiography, Studies in Philosophy and Education, 23(5), 445-466.

Fine, G.A. \& Martin, D.D. (1990) A Partisan View: sarcasm, satire and irony as voices in Erving Goffman's Asylums, Journal of Contemporary Ethnography, 19(10), 89-115.

Gibbs, R.W. (2007) On the Psycholinguistics of Sarcasm, in R.W. Gibbs \& H.L. Colston (Eds), Irony in Language and Thought, pp. 173-200. New York: Lawrence Erlbaum Associates.

Goffman, E. ([1961] 1991) Asylums. New York: Anchor Books.

Gunter, H. (1995) Jurassic Management: chaos and management development in educational institutions, Journal of Educational Administration, 33(4), 5-20.

Hackley, C. (2007) Auto-ethnographic Consumer Research and Creative Non-fiction, International Journal, 10(1), 98-108.

Harris, R. (1990) The Purpose and Method of Satire, Virtual Salt, 1-11. http: / / www.virtualsalt.com/satire.htm

Higher Education Funding Council for England (HEFCE) (2005) Transparent Approach to Costing: a review of trac. London: HEFCE. http:/ / www.jcpsg.ac.uk/downloads/guidance/Overview.pdf

Holligan, C. (2011) Feudalism and Academia: UK academics' accounts of research culture, International Journal of Qualitative Studies in Education, 24(1), 55-75. http: / / dx.doi.org/10.1080/09518398.2010.485134

Holloway, J. (1956) The Well-filled Dish: an analysis of Swift's satire, Hudson Review, 9(1), 20-37.

Humes, W. (2011) Probing the Limits of Collaboration: professional identity and institutional power, in J. Forbes \& C. Watson (Eds) The Transformation of Children's Services: examining and debating the complexities of inter/professional working. London: Routledge.

Johnsen, R., Muhr, S.L. \& Pedersen, M. (2009) The Frantic Gesture of Interpassivity, Management, 22(2), 202-213.

Kavanagh, D. (2009) Institutional Heterogeneity and Change: the university as fool, Organization, 16(4), 575-595.

Kierkegaard, S. ([1846] 2009) Concluding Unscientific Postscript. Cambridge: Cambridge University Press.

Knight, C.A. (1992) Satire, Speech, and Genre, Comparative Literature, 44(1), 22-41.

Knight, C.A. (2004) The Literature of Satire. Cambridge: Cambridge University Press.

Lippitt, J. (1999) Illusion and Satire in Kierkegaard's Postscript, Continental Philosophy Review, 32(4), 451-466.

MacLure, M. (2006) A Demented Form of the Familiar: postmodernism and educational research, Journal of Philosophy of Education, 40(2), 223-239.

Muecke, D.C. (1982) Irony and the Ironic. London: Methuen.

Munday, I. (2009) Heidegger, Ethics and Ontological Education: a critical response to Nobuhiko Itani's paper 'Beyond the Self, Record of Clinical-Philosophical Pedagogy, 9,76-87.

Nowotny, H., Scott, P. \& Gibbons, M. (2003) Mode 2 Revisited: the new production of knowledge, Minerva, 41(3), 179-194.

Polak, F. (1961) The Image of the Future, vol. II. New York: Oceana Publications.

Real, J.H. (2005) Satiric Narrative, in D. Herman, M. Jahn \& M.-L. Ryan (Eds) Routledge Encyclopedia of Narrative, pp.512-513. London: Routledge.

Sparkes, A.C. (2007) Embodiment, Academics, and the Audit Culture: a story seeking consideration, Qualitative Research, 7(4): 521-550.

Spieker, S. (1995) Gogol and the Baroque, Slavic and East European Journal, 39(2), 277-282.

Stronach, I. (2007) On Promoting Rigour in Educational Research: the example of the RAE, Journal of Education Policy, 22(3), 343-352.

Strong, P.M. (1983) The Importance of Being Erving: Erving Goffman, 1922-1982, Sociology of Health \& Illness, 5(3), 345-355. 
Urry, J. (2002) Globalizing the Academy, in K. Robins \& F. Webster (Eds) The Virtual University? Oxford: Oxford University Press.

van Oenen, G. (2008) Interpassivity Revisited: a critical and historical reappraisal of interpassive phenomena, International Journal of Žižek Studies, 2(2), 1-16.

Veblen, T. (1899) The Theory of the Leisure Class. New York: MacMillan.

Virilio, P. (2001) Paul Virilio: live selected interviews. London: Sage.

Virilio, P. (2007) The Original Accident. Cambridge: Polity Press.

Watson, C. (2008) Reflexive Research and the (Re)turn to the Baroque (or, how I learned to stop worrying and love the university). Rotterdam: Sense.

Watson, C. (2010) Accountability, Transparency, Redundancy: academic identities in an era of 'excellence', British Educational Research Journal. http: / / dx.doi.org/10.1080/01411926.2010.508514

Weick, K.E. (1989) Theory Construction as Disciplined Imagination, Academy of Management Review, 14(4), 516-531.

Whiteman, G. \& Phillips, N. (2006) The Role of Narrative Fiction and Semi-fiction in Organizational Studies, ERIM Report Series Research in Management, December. http: / / repub.eur.nl/res/pub/9731/ERS-2006-079-ORG.pdf

Žižek, S. (1998) The Interpassive Subject. Traverses. http:/ / homepage.newschool.edu/ quigleyt/vcs/interpassive.pdf

CATE WATSON is a senior lecturer in the School of Education, University of Stirling. Her main research interests lie in institutional/professional identities and professional knowledge/learning. She is also interested in narrative as a research methodology and has published widely in this area. She is the author of Reflexive Research and the (Re)turn to the Baroque (or, how I learned to stop worrying and love the university) (2008, Sense), and has co-edited (with Joan Forbes) Service Integration in Schools, Research and Policy Discourses, Practices and Future Prospects (2009, Sense) and The Transformation of Children's Services: examining and debating the complexities of inter/professional working (Routledge, 2011). Correspondence: Cate Watson, School of Education, University of Stirling, Stirling FK9 4LA, United Kingdom (cate.watson@stir.ac.uk). 